\title{
21. INTERSTITIAL WATER CHEMISTRY DEEP SEA DRILLING PROJECT, LEG $5^{1}$
}

\author{
B. J. Presley, M. B. Goldhaber and R. I. Kaplan \\ Department of Geology and Institute of Geophysics and Planetary Physics \\ University of California, Los Angeles, California
}

\section{INTRODUCTION}

The interstitial water received at UCLA from Leg 5 consisted of twenty-three samples of approximately 5 milliliters each, four samples of approximately 100 milliliters each, and four samples of approximately 10 milliliters each. The 5-milliliter samples were sealed in plastic syringes on board ship by heat sealing the tip and pouring RTV silicon rubber around the plunger. These samples and the larger samples, which were stored in polyethylene, were refrigerated, except for the time in shipment to UCLA from Scripps Institution of Oceanography. The four 10-milliliter samples were frozen in polyethylene bottles on board ship, and were kept frozen until analysis began at UCLA. All samples were filtered through a 0.45 -micron filter before storage.

Analysis was started as soon as the samples had arrived at UCLA, nevertheless, this was a time lapse of as long as three months for some samples after their retrieval.

The 5-milliliter samples were intended primarily for total carbon-dioxide and carbon isotope measurements; these were the first samples UCLA had received that were sealed in plastic syringes. This method of storage is convenient for the shipboard technicians, but-as will be mentioned below-it lead to some initial handling problems in the laboratory.

\section{EXPERIMENTAL PROCEDURES AND RESULTS}

The tip of the plastic syringe was cut off with a scalpel, and 3 to 4 milliliters of the water were injected into a small reaction flask; the remainder was injected into a plastic vial. The flask was emersed in liquid nitrogen to quick-freeze the sample then, while still in the liquid nitrogen, one milliliter of 1 normal hydrochloric acid was added, and the flask was quickly closed with a stopcock. The flasks were evacuated while in liquid nitrogen, then the sample and acid were allowed to thaw and react. The evolved carbon dioxide was purified, measured, and collected on a vacuum line similar to that described by McCrea (1950).

\footnotetext{
${ }^{1}$ Publication no. 837 Institute of Geophysics and Planetary Physics.
}

This procedure gave volumes considerably higher than those calculated from an alkalinity titration by the Woods Hole scientists (they misinterpreted the UCLA units and reported the values which had been supplied to them as being lower than their own, see Manheim et al., this volume). Furthermore, the $\delta \mathrm{C}^{13}$ values were in the range -10 to -15 per mil, considerably lower than is reasonable, unless biological activity has been intense in the sediment column. The high volumes and low carbon isotope ratios are probably due to atmospheric carbon dioxide contamination during freezing of the sample, since only a small amount of contaminant is needed to affect the data greatly when working with small samples-as the authors subsequently have found. For this reason, the data is not reported here. Instead, values for total carbon dioxide obtained by gas chromatography on board ship are given. These are listed in Table 1, where it can be seen that they agree well with the Woods Hole bicarbonate values for all but a few samples.

The water used for the laboratory total carbon-dioxide measurement was also used for manganese, zinc and sulfate analyses. This was done by adding 5 milliliters of distilled water to the acidified sample in the carbonate reaction flask after removal of the carbon dioxide, and measuring the total volume by pouring it into a graduated cylinder. One milliliter of this total was removed for manganese and zinc analyses by atomic absorption, spectrophotometry; the remainder was washed into a beaker and the sulfate precipitated as barium sulfate, which was filtered, dried and weighed. The original sample volume calculated from the volume as measured in a graduated cylinder is not very exact, and the sulfate results show more scatter than is reasonable. This inexact volume determination also explains the disagreement between some of the UCLA sulfate results and those of the Woods Hole group. In cases where there is such disagreement, the authors believe that the values of Manheim et al. are more reliable. Subsequent to Leg 6, the amount of sample used has been determined by weighing, and more consistent results have been obtained.

One milliliter of the raw sample remaining after removal of the aliquot for carbon dioxide, zinc, manganese and sulfate measurements was used for a Mohr chloride titration. The resulting values, which were originally 
TABLE 1

Shipboard Data on Interstitial Water, Leg 5

\begin{tabular}{|c|c|c|c|c|c|}
\hline $\begin{array}{c}\text { Sample } \\
\text { Designation }\end{array}$ & $\begin{array}{c}\text { Depth } \\
\text { Below Sea Bed } \\
\text { (m) }\end{array}$ & $p \mathrm{H}$ & $\begin{array}{c}\mathrm{Eh} \\
(\mathrm{mv})\end{array}$ & $\underset{(\mathrm{mM} / \mathrm{Kg})}{\sum \mathrm{CO}_{2}}$ & $\begin{array}{r}\mathrm{HCO}_{3}^{-\mathrm{a}} \\
(\mathrm{mM} / \mathrm{Kg})\end{array}$ \\
\hline $32-1-3$ & 4 & 8.6 & +422 & 6.2 & 7.2 \\
\hline $32-4-4$ & 97 & 8.4 & +445 & 8.8 & 6.6 \\
\hline $32-6-6$ & 116 & 7.6 & +472 & 8.8 & 8.4 \\
\hline $32-8-1$ & 168 & 7.6 & +484 & 6.0 & 5.7 \\
\hline $32-10-3$ & 188 & 7.6 & +460 & 4.8 & 5.4 \\
\hline $32-12-2$ & 206 & 7.1 & +477 & 3.4 & 4.0 \\
\hline $33-1-6$ & 8 & 7.9 & +452 & 5.6 & 5.9 \\
\hline $33-3-3$ & 51 & 7.5 & +454 & 7.6 & 8.2 \\
\hline $33-4-3$ & 99 & 7.5 & +432 & 6.0 & 7.0 \\
\hline $33-5-6$ & 160 & 7.6 & +452 & 6.2 & 6.2 \\
\hline $33-6-6$ & 227 & 7.3 & +562 & 5.4 & 6.1 \\
\hline $33-8-3$ & 235 & 7.3 & +447 & 6.2 & 6.7 \\
\hline $33-10-5$ & 263 & 7.4 & +432 & 1.9 & 2.6 \\
\hline $34-1-4$ & 25 & 7.8 & +412 & 5.6 & 8.0 \\
\hline $34-3-5$ & 82 & 7.1 & +454 & 4.6 & 4.1 \\
\hline $34-5-2$ & 118 & 7.6 & +452 & 7.6 & 6.7 \\
\hline $34-7-6$ & 142 & 7.9 & +412 & 3.9 & 5.1 \\
\hline $34-8-6$ & 173 & 7.7 & +442 & 5.7 & 7.0 \\
\hline $34-9-5$ & 219 & 7.6 & +464 & 2.8 & 3.0 \\
\hline $34-10-3$ & 271 & 7.6 & +484 & 1.9 & 3.0 \\
\hline $34-11-2$ & 280 & 7.6 & +444 & 2.2 & 3.4 \\
\hline $34-14-2$ & 340 & 7.1 & +502 & 2.8 & 2.8 \\
\hline $35-2-2$ & 41 & 8.3 & +427 & 19.3 & 17.7 \\
\hline $35-6-2$ & 160 & 8.2 & +432 & 13.6 & 17.0 \\
\hline $35-7-3$ & 237 & 8.1 & +432 & 11.7 & 4.6 \\
\hline $35-9-2$ & 287 & 7.9 & +447 & 1.0 & 2.8 \\
\hline $35-12-6$ & 330 & 7.6 & +477 & 1.2 & 2.8 \\
\hline $35-13-4$ & 350 & 7.8 & +424 & 1.4 & 3.9 \\
\hline $35-14-4$ & 360 & 7.7 & +497 & 1.8 & 4.3 \\
\hline $36-2-1$ & 10 & 7.7 & +410 & 3.0 & 4.3 \\
\hline $36-4-3$ & 21 & 7.8 & +432 & 2.7 & 3.6 \\
\hline $36-6-6$ & 56 & 7.6 & +512 & 2.4 & 3.0 \\
\hline $36-8-1$ & 67 & - & +432 & 2.5 & 4.1 \\
\hline $36-10-5$ & 90 & 7.9 & +402 & 2.8 & 3.3 \\
\hline $36-12-3$ & 106 & 7.9 & +480 & 1.9 & 2.8 \\
\hline
\end{tabular}


TABLE 1 - Continued

\begin{tabular}{lccccc}
\hline $\begin{array}{c}\text { Sample } \\
\text { Designation }\end{array}$ & $\begin{array}{c}\text { Depth } \\
\text { Below Sea Bed } \\
(\mathrm{m})\end{array}$ & $p \mathrm{H}$ & $\begin{array}{c}\mathrm{Eh} \\
(\mathrm{mv})\end{array}$ & $\begin{array}{c}\sum \mathrm{CO}_{2} \\
(\mathrm{mM} / \mathrm{Kg})\end{array}$ & $\begin{array}{c}\mathrm{HCO}_{3}^{-\mathrm{a}} \\
(\mathrm{mM} / \mathrm{Kg})\end{array}$ \\
\hline $37-1-2$ & 2 & 7.5 & +514 & 3.1 & 4.4 \\
$37-3-1$ & 15 & 7.3 & +532 & 3.0 & 3.1 \\
$38-2-4$ & 8 & 7.8 & +527 & 2.3 & 3.1 \\
$38-4-2$ & 24 & 7.2 & +504 & - & 3.8 \\
$38-6-4$ & 45 & 7.3 & +572 & 2.4 & 3.0 \\
$39-1-3$ & 4 & 7.1 & +524 & 2.8 & 3.0 \\
$40-1-3$ & 4 & 6.9 & +525 & 2.7 & 2.8 \\
$40-8-3$ & 70 & 7.3 & +507 & 2.5 & 2.8 \\
$40-14-3$ & 125 & 7.4 & +512 & - & 2.6 \\
$40-16-3$ & 142 & 7.8 & +512 & 2.8 & 2.8 \\
$41-1-3$ & 4 & 6.9 & +520 & 2.4 & 2.6 \\
$42-1-3$ & 4 & 7.1 & +534 & 1.0 & 2.5 \\
$42-4-3$ & 31 & 7.4 & +527 & 3.0 & - \\
$42-6-4$ & 51 & 7.2 & +495 & 3.0 & 2.8 \\
$42-8-5$ & 71 & 7.3 & +532 & 3.2 & 3.0 \\
$42-10-3$ & 86 & 7.5 & +512 & 3.0 & 5.1 \\
$43-2-2$ & 5 & 7.3 & +482 & - & 3.0 \\
Surface & & & & & 2.4 \\
seawater & 0.2 & +450 & 2.7 & \\
\hline
\end{tabular}

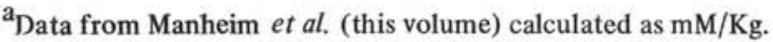

calculated as grams per liter and converted to grams per kilogram by assuming a room temperature density of $1.024 \mathrm{~g} / \mathrm{ml}$ for the sample, are given in Table 1 . It was found unnecessary to use critical tables giving salinities from chlorinity, and densities for various salinities and temperatures in order to make the conversion, since the difference fell within the experimental error of the method. A comparison of UCLA chlorinity values with those of Manheim et al. (this volume) show remarkably good agreement, considering the differences in sample handling and the small sample size. There is a bias in the results, however, since the UCLA values are greater than the Woods Hole chlorinity values except for two samples, where they are equal. In eleven out of the twenty-three samples which were analyzed in common, the UCLA value is higher by $0.3 \mathrm{~g} / \mathrm{kg}$ or about 1.5 per cent, and only one sample differs by as much as $0.5 \mathrm{~g} / \mathrm{kg}$ or 2.5 per cent.
The remaining 1 milliliter of raw sample was used for sodium, magnesium, calcium, potassium, lithium, boron, strontium and bromine determinations. This was done by first adding 5 milliliters of distilled water to the plastic vials which contained the 1-milliliter sample, thereby making a 6 to $1 \mathrm{~V} / \mathrm{V}$ dilution (this is not strictly true because of non-ideal mixing, but the effect is too small to be of significance). One milliliter of this 6 to 1 dilution was further diluted by 20 to 1 with a 1 per cent lanthanum solution and the resulting 120 to 1 dilution was used for the potassium and calcium determination by atomic absorption spectrophotometry (AAS).

One milliliter of the 120 to 1 dilution was further diluted 10 to 1 with distilled water and used for magnesium determination by AAS. 
One milliliter of the 120 to 1 dilution was diluted 100 to 1 with distilled water and used for sodium determination by AAS.

Two milliliters of the 6 to 1 dilution were used for bromine determination by a modification of the colorimetric method of Baltre (1936).

One milliliter of the 6 to 1 dilution was used for boron determination by a modification of the colorimetric method of Hays and Metcalfe (1962).

The remaining 2 milliliters of the 6 to 1 dilution were used to determine lithium and strontium by flame photometry and AAS, respectively.

The data from these determinations are given in Tables 2 and 3 , and are compared to the Woods Hole data in the report by Manheim et al. (this volume).

The trace elements iron, cobalt, nickel and copper were determined by AAS after concentration by the solvent extraction technique of Brooks et al. (1967). These values are given in Table 4.

The 10-milliliter frozen samples, which were aliquots of the large trace element samples, were used for silicon and phosphate determinations following the procedure of Strickland and Parsons (1968). The silicon values are given in Table 4 . Three out of the 4 values agree with values determined by the Woods Hole group for nearby samples, but the fourth differs by an order of magnitude. The Woods Hole value for this sample seems more reasonable, and the authors have no explanation for the low UCLA value.

The phosphate content of the frozen samples proved to be below the detection limit of the method used (about $1 \mathrm{ppm}$ ); therefore these waters are not enriched in phosphate as many of the interstitial waters from coastal sediments analyzed in this laboratory have proven to be (Brooks et al., 1968).

\section{DISCUSSION}

In extensive work on interstitial water chemistry (Brooks et al., 1968; Presley et al., 1967, 1968; Presley, 1969) the authors have found that, with the exception of manganese, transition metals occur in only trace amounts in interstitial water, rarely exceeding $1 \mathrm{ppm}$ in concentration. This means that the metal content of a relatively large volume of interstitial water (ideally $>100$ milliliters) must be concentrated (Brooks et al., 1968 ) into a small volume (5 milliliters, for example) to obtain reliable data with the present techniques. These large volumes of interstitial water are difficult to obtain because of the need to process relatively large sections of sediment and the time required to obtain a water sample. Therefore, only four samples per leg are being specially prepared for this purpose.

Obviously, no concentration trends with depth will be revealed when only one such sample per hole is analyzed, but any anomalies (such as, possible exhalations from depth) may be found, and a pattern relating trace metal concentration to sediment type may be established, especially when other data can be correlated.

All four samples from the present leg (Table 4) show higher iron concentrations than were typical of the Leg 4 Atlantic cores (where, incidentally, many more samples were analyzed). The iron concentrations are also significantly higher than the values typically found in either near-shore or deep sea oxidizing sediments collected by piston coring. It is especially interesting that Sample 40-15-5, which is a radiolarian ooze and might be expected to have low dissolved iron content, in fact, shows the highest concentration. This same phenomenon occurs in Hole 29 from Leg 4. The bottom sample there, which is the only radiolarian ooze, shows an iron content an order of magnitude higher than other samples from that hole. However, Sample 42-10-2 is reported to be partially radiolarian ooze, and yet has a relatively low iron content. It will be interesting to see in the future if similar samples are enriched in iron.

The copper content of Leg 5 samples is significantly higher than was typical of the Atlantic samples (with the exception of samples from areas of sulfate reduction), but the nickel and cobalt contents are similar. No pattern in the concentration distribution is yet apparent for these three elements.

Zinc concentrations are variable, but are always much higher than seawater values. As was deduced from the Leg 4 results, this could be due to contamination from the paint used on the drill pipe.

Manganese concentrations are also highly variable, and often show large enrichments, a phenomenon which the authors reported more than two years ago, but which they still can not explain satisfactorily. It is hoped that a planned closer study of the mineralogy of the cores will shed light on this phenomenon.

The $\mathrm{E} h$ and $p \mathrm{H}$ obtained by equipment placed on board ship by UCLA (Table 1) is also difficult to interpret at this time. The technicians repeatedly standardize the $p \mathrm{H}$ electrode with fresh buffer solutions, and always obtain a reasonable $p \mathrm{H}$ for fresh local seawater, yet many of the interstitial water $p \mathrm{H}$ values are surprisingly low. A $p \mathrm{H}$ of 6.9 was recorded for Sample 40-1-3, which should be buried only four meters below the sediment surface. This could represent an error in recording, but it is also possible that a redox reaction occurred before or during squeezing. Small manganese 
TABLE 2

Major Constituents of Interstitial Water, Leg 5

\begin{tabular}{|c|c|c|c|c|c|c|c|c|c|c|c|}
\hline $\begin{array}{l}\text { Sample } \\
\text { Designation }^{\mathrm{a}}\end{array}$ & $\begin{array}{c}\text { Depth } \\
\text { Below } \\
\text { Sea Bed } \\
\text { (m) }\end{array}$ & Age & Description & $\begin{array}{l}\mathrm{Na} \\
(\mathrm{g} / \mathrm{kg})\end{array}$ & $\begin{array}{l}\mathrm{Mg} \\
(\mathrm{g} / \mathrm{kg})\end{array}$ & $\begin{array}{c}\mathrm{K} \\
(\mathrm{mg} / \mathrm{kg})\end{array}$ & $\begin{array}{c}\mathrm{Ca} \\
(\mathrm{mg} / \mathrm{kg})\end{array}$ & $\begin{array}{c}\text { Total } \\
\text { Cations } \\
\text { (meq/kg) }\end{array}$ & $\underset{(\mathrm{g} / \mathrm{kg})}{\mathrm{Cl}}$ & $\begin{array}{l}\mathrm{SO}_{4} \\
(\mathrm{~g} / \mathrm{kg})\end{array}$ & $\begin{array}{l}\text { Total }^{\mathrm{b}} \\
\text { Anions } \\
\text { (meq } / \mathrm{kg})\end{array}$ \\
\hline \multicolumn{12}{|c|}{ Hole $34\left(39^{\circ} 28.21^{\prime} \mathrm{N}, 127^{\circ} 16.54^{\prime} \mathrm{W}\right.$, water depth $4322 \mathrm{~m} ., 200$ miles W. of Cape Mendocino, Calif.) } \\
\hline $1-4(81-89)$ & 25 & Pleistocene & Gray-green clay, ash streaks & 11.3 & 1.19 & - & 387 & - & 19.6 & 2.49 & 611 \\
\hline $3-5(95-105)$ & 82 & Upper Pliocene & Nannofossil chalk ooze & 11.4 & 1.12 & 424 & 347 & 616 & 19.6 & 2.02 & 608 \\
\hline $4-4(-)$ & 110 & Lower Pliocene & Clay mud, nannofossil patches & 10.6 & 1.02 & 412 & 468 & 589 & - & - & - \\
\hline $5-2(82-93)$ & 118 & Lower Pliocene & Clay mud, glass, pyrite & 10.9 & 1.04 & 374 & 474 & 593 & 19.5 & 1.86 & 593 \\
\hline $7-6(39-50)$ & 142 & Upper Miocene & Clay mud, patches nannofossil & 11.3 & 1.03 & 430 & 468 & 611 & 19.9 & 1.54 & 599 \\
\hline $8-6(103-114)$ & 173 & Upper Miocene & Clay mud, siliceous fossils, ash & 10.7 & 0.96 & 363 & 551 & 581 & 19.7 & 1.72 & 595 \\
\hline $9-5(108-122)$ & 219 & Middle Miocene & Firm siliceous clay, mottled & 10.5 & 0.88 & 363 & 595 & 572 & 19.8 & 1.57 & 593 \\
\hline $10-3(14-24)$ & 271 & Middle Miocene & Siliceous clay-mud, nannofossil & 11.0 & 0.84 & 330 & 710 & 591 & 19.5 & 1.33 & 580 \\
\hline $11-2(115-130)$ & 280 & Middle Miocene & Siliceous clay-mud, nannofossil pods & 11.4 & 0.71 & 313 & 721 & 598 & 19.6 & 1.48 & 587 \\
\hline \multicolumn{12}{|c|}{ Hole $36\left(40^{\circ} 59.08^{\prime} \mathrm{N}, 130^{\circ} 06.58^{\prime} \mathrm{W}\right.$, water depth $3273 \mathrm{~m} ., 400$ miles W. of Cape Mendocino, Calif.) } \\
\hline $2-1(80-91)$ & 10 & Pleistocene & $\begin{array}{l}\text { Olive-gray foraminiferal-coccolithic } \\
\text { ooze }\end{array}$ & 10.8 & 1.22 & 451 & 374 & 600 & 19.7 & 2.82 & 618 \\
\hline $4-3(98-111)$ & 31 & $\begin{array}{l}\text { Pliocene- } \\
\text { Pleistocene }\end{array}$ & $\begin{array}{l}\text { Green-gray foraminiferal-coccolithic } \\
\text { ooze }\end{array}$ & 10.8 & 1.10 & - & 347 & - & 19.5 & 2.18 & 597 \\
\hline $6-6(98-111)$ & 56 & Upper Pliocene & $\begin{array}{l}\text { Light gray-green foraminiferal-disco- } \\
\text { coccolithic ooze }\end{array}$ & 10.6 & 1.22 & 462 & 352 & 590 & 19.5 & 2.71 & 609 \\
\hline $8-1(86-96)$ & 67 & Lower Pliocene & $\begin{array}{l}\text { Greenish-gray foraminiferal disco- } \\
\text { coccolithic ooze }\end{array}$ & 11.4 & 1.18 & 562 & 363 & 625 & 19.8 & 2.57 & 615 \\
\hline $10-5(105-114)$ & 90 & Lower Pliocene & Greenish-gray clayey nannofossil ooze & e 10.6 & 1.23 & 444 & 374 & 592 & 19.4 & 3.03 & 613 \\
\hline $11-0(-)$ & 92 & Lower Pliocene & $\begin{array}{l}\text { Dark green clayey mud } \\
(10 \% \text { nannofossil })\end{array}$ & 10.4 & 1.16 & 500 & 384 & 584 & - & - & - \\
\hline $12-3(80-91)$ & 106 & Upper Miocene & Green clayey mud ( $70 \%$ nannofossil) & 10.9 & 1.18 & 474 & 352 & 601 & 19.4 & 3.08 & 613 \\
\hline
\end{tabular}




\begin{tabular}{|c|c|c|c|c|c|c|c|c|c|c|c|}
\hline $\begin{array}{c}\text { Sample } \\
\text { Designation }^{\mathrm{a}}\end{array}$ & $\begin{array}{c}\text { Depth } \\
\text { Below } \\
\text { Sea Bed } \\
\text { (m) }\end{array}$ & Age & Description & $\underset{(\mathrm{g} / \mathrm{kg})}{\mathrm{Na}}$ & $\underset{(\mathrm{g} / \mathrm{kg})}{\mathrm{Mg}}$ & $\underset{(\mathrm{mg} / \mathrm{kg})}{\mathrm{K}}$ & $\underset{(\mathrm{mg} / \mathrm{kg})}{\mathrm{Ca}}$ & $\begin{array}{c}\text { Total } \\
\text { Cations } \\
\text { (meq } / \mathrm{kg})\end{array}$ & $\underset{(\mathrm{g} / \mathrm{kg})}{\mathrm{Cl}}$ & $\begin{array}{c}\mathrm{SO}_{4} \\
(\mathrm{~g} / \mathrm{kg})\end{array}$ & $\begin{array}{c}\text { Total }^{\mathrm{b}} \\
\text { Anions } \\
\text { (meq } / \mathrm{kg} \text { ) }\end{array}$ \\
\hline \multicolumn{12}{|c|}{ Hole $40\left(19^{\circ} 47.57^{\prime} \mathrm{N}, 139^{\circ} 54.08^{\prime} \mathrm{W}\right.$, water depth $5183 \mathrm{~m} ., 1000$ miles E. of Hawaii) } \\
\hline $1-3(29-39)$ & 3 & Unknown age & Zeolitic red clay & 11.0 & 1.18 & 446 & 374 & 605 & 19.4 & 2.65 & 606 \\
\hline $8-3(80-90)$ & 70 & Middle Eocene & $\begin{array}{l}\text { Brown-radiolarian ooze }(5 \% \\
\text { clay) }\end{array}$ & 10.9 & 1.30 & 413 & 407 & 612 & 19.9 & 2.90 & 625 \\
\hline $14-3(80-90)$ & 125 & Lower Eocene & Brown-radiolarian ooze & 10.9 & 1.30 & 478 & 391 & 613 & 19.9 & 2.64 & - \\
\hline $15-3(-)$ & 136 & Lower Eocene & Brown-radiolarian ooze & 10.8 & 1.20 & 395 & 386 & 598 & - & - & - \\
\hline $16-3(31-42)$ & 142 & Lower Eocene & Brown-radiolarian ooze & 10.9 & 1.30 & 398 & 391 & 611 & 19.9 & 2.85 & 623 \\
\hline \multicolumn{12}{|c|}{ Hole $42\left(13^{\circ} 50.56^{\prime} \mathrm{N}, 140^{\circ} 11.31^{\prime} \mathrm{W}\right.$, water depth $4848 \mathrm{~m} ., 500$ miles S. of Hole 40$)$} \\
\hline $1-3(110-120)$ & 4 & Upper Oligocene & $\begin{array}{l}\text { Orange to yellow-brown radiolarian- } \\
\text { nannofossil ooze (firm) }\end{array}$ & 10.9 & 1.28 & 457 & 386 & 610 & 19.8 & 2.63 & 614 \\
\hline $4-3(110-120)$ & 31 & Lower Oligocene & Radiolarian-nannofossil ooze & 10.4 & 1.31 & 468 & 451 & 600 & 19.9 & 2.76 & 622 \\
\hline $6-4(15-25)$ & 51 & Upper Eocene & $\begin{array}{l}\text { Yellow-medium brown radiolarian- } \\
\text { nannofossil ooze }\end{array}$ & 10.8 & 1.25 & 413 & 440 & 606 & 19.8 & 2.63 & 616 \\
\hline $8-5(90-102)$ & 70 & Middle Eocene & $\begin{array}{l}\text { Radiolarian-nannofossil ooze, } \\
\text { pumice fragment }\end{array}$ & 11.0 & 1.27 & 407 & 446 & 615 & 19.7 & 2.83 & 609 \\
\hline $10-2(-)$ & 84 & Middle Eocene & Firm radiolarian-nannofossil ooze & 10.8 & 1.21 & 405 & 459 & 603 & - & - & - \\
\hline $10-3(79-89)$ & 86 & Middle Eocene & $\begin{array}{l}\text { Firm radiolarian-nannofossil ooze, } \\
\text { pumice fragment }\end{array}$ & 11.5 & 1.34 & 401 & 468 & 644 & 19.9 & - & - \\
\hline \multicolumn{4}{|c|}{ Sea Water (Culkin, 1965) } & 10.76 & 1.29 & 387 & 413 & 607 & 19.35 & 2.71 & 604 \\
\hline
\end{tabular}

${ }^{\mathrm{a}}$ Core-Section (interval).

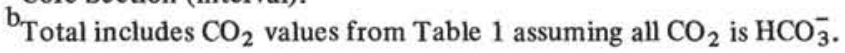


TABLE 3

Minor Constituents of Interstitial Water, Leg 5

\begin{tabular}{|c|c|c|c|c|c|c|c|c|c|}
\hline $\begin{array}{l}\text { Sample } \\
\text { Designation }^{\mathrm{a}}\end{array}$ & $\begin{array}{l}\text { Depth } \\
\text { Below } \\
\text { Sea Bed } \\
\text { (m) }\end{array}$ & Age & Description & $\underset{(\mu \mathrm{g} / \mathrm{kg})}{\mathrm{Li}}$ & $\begin{array}{c}\mathrm{B} \\
(\mathrm{mg} / \mathrm{kg})\end{array}$ & $\begin{array}{c}\mathrm{Sr} \\
(\mathrm{mg} / \mathrm{kg})\end{array}$ & $\begin{array}{c}\mathrm{Br} \\
(\mathrm{mg} / \mathrm{kg})\end{array}$ & $\begin{array}{l}\mathrm{Mn} \\
(\mathrm{mg} / \mathrm{kg})\end{array}$ & $\begin{array}{c}\mathrm{Zn} \\
(\mathrm{mg} / \mathrm{kg})\end{array}$ \\
\hline \multicolumn{10}{|c|}{ Hole $34\left(39^{\circ} 28.21^{\prime} \mathrm{N}, 127^{\circ} 16.54^{\prime} \mathrm{W}\right.$, water depth $4322 \mathrm{~m} ., 200$ miles W. of Cape Mendocino, Calif.) } \\
\hline $1-4(81-89)$ & 25 & Pleistocene & Gray-green clay, ash streaks & 174 & - & 7.1 & 49 & 1.80 & 0.44 \\
\hline $3-5(95-105)$ & 82 & Upper Pliocene & Nannofossil chalk ooze & 254 & 4.7 & 7.2 & 57 & 1.14 & 0.78 \\
\hline $4-4(-)$ & 110 & Lower Pliocene & Clay mud, nannofossil patches & 391 & - & - & - & - & 0.19 \\
\hline $5-2(82-93)$ & 118 & Lower Pliocene & Clay mud, glass, pyrite & 313 & - & 7.8 & - & 1.83 & 0.52 \\
\hline $7-6(39-50)$ & 142 & Upper Miocene & Clay mud, patches nannofossils & 366 & 3.3 & 7.6 & 66 & 0.62 & 0.42 \\
\hline $8-6(103-114)$ & 173 & Upper Miocene & Clay mud, siliceous fossils, ash & 415 & 3.8 & 8.7 & 64 & 1.31 & 0.47 \\
\hline $9-5(108-122)$ & 219 & Middle Miocene & Firm siliceous clay, mottled & 469 & 4.5 & 8.7 & 69 & 0.90 & 0.72 \\
\hline $10-3(14-24)$ & 271 & Middle Miocene & Siliceous clay-mud, nannofossils & 498 & 4.3 & 9.2 & 74 & 0.75 & 0.26 \\
\hline $11-2(115-130)$ & 280 & Middle Miocene & Siliceous clay-mud, nannofossil pods & 498 & 3.9 & 8.7 & 62 & 0.75 & 0.28 \\
\hline \multicolumn{10}{|c|}{ Hole $36\left(40^{\circ} 59.08^{\prime} \mathrm{N}, 130^{\circ} 06.58^{\prime} \mathrm{W}\right.$, water depth $3273 \mathrm{~m} ., 400$ miles W. of Cape Mendocino, Calif.) } \\
\hline $2-1(80-91)$ & 10 & Pleistocene & $\begin{array}{l}\text { Olive-gray foraminiferal-coccolithic } \\
\text { ooze }\end{array}$ & 156 & 6.1 & 7.5 & 59 & 4.83 & 0.51 \\
\hline $4-3(98-111)$ & 31 & Pliocene-Pleistocene & $\begin{array}{l}\text { Green-gray foraminiferal-coccolithic } \\
\text { ooze }\end{array}$ & 158 & 4.9 & 7.3 & 58 & 2.79 & 0.37 \\
\hline $6-6(98-111)$ & 56 & Upper Pliocene & $\begin{array}{l}\text { Light gray-green foraminiferal-disco- } \\
\text { coccolithic ooze }\end{array}$ & 160 & 5.2 & 6.9 & 64 & 3.22 & 1.69 \\
\hline $8-1(86-96)$ & 67 & Lower Pliocene & $\begin{array}{l}\text { Greenish-gray foraminiferal-disco- } \\
\text { coccolithic ooze }\end{array}$ & 170 & 3.1 & 7.1 & 58 & 2.30 & 0.28 \\
\hline $10-5(105-114)$ & 90 & Lower Pliocene & Greenish-gray clayey nannofossil ooze & 168 & - & 6.9 & 55 & 2.30 & 0.33 \\
\hline $11-0(-)$ & 92 & Lower Pliocene & $\begin{array}{l}\text { Dark green clayey mud ( } 10 \% \text { nanno- } \\
\text { fossil) }\end{array}$ & 215 & - & - & - & 2.44 & 0.21 \\
\hline $12-3(80-91)$ & 106 & Upper Miocene & Green clayey mud (70\% nannofossil) & - & 3.9 & 6.9 & 60 & 0.90 & 0.31 \\
\hline
\end{tabular}


TABLE 3 -Continued

\begin{tabular}{|c|c|c|c|c|c|c|c|c|c|}
\hline $\begin{array}{l}\text { Sample } \\
\text { Designation }^{\mathrm{a}}\end{array}$ & $\begin{array}{c}\text { Depth } \\
\text { Below } \\
\text { Sea Bed } \\
\text { (m) }\end{array}$ & Age & Description & $\begin{array}{c}\mathrm{Li} \\
(\mu \mathrm{g} / \mathrm{kg})\end{array}$ & $\begin{array}{c}\mathrm{B} \\
(\mathrm{mg} / \mathrm{kg})\end{array}$ & $\underset{(\mathrm{mg} / \mathrm{kg})}{\mathrm{Sr}}$ & $\underset{(\mathrm{mg} / \mathrm{kg})}{\mathrm{Br}}$ & $\begin{array}{c}\mathrm{Mn} \\
(\mathrm{mg} / \mathrm{kg})\end{array}$ & $\underset{(\mathrm{mg} / \mathrm{kg})}{\mathrm{Zn}}$ \\
\hline \multicolumn{10}{|c|}{ Hole $40\left(19^{\circ} 47.57^{\prime} \mathrm{N}, 139^{\circ} 54.08^{\prime} \mathrm{W}\right.$, water depth $5183 \mathrm{~m} ., 1000$ miles E. of Hawaii) } \\
\hline $1-3(29-39)$ & 3 & Unknown age & Zeolitic red clay & 174 & - & 7.3 & 60 & 0.1 & 0.70 \\
\hline $8-3(80-90)$ & 70 & Middle Eocene & Brown-radiolarian ooze ( $5 \%$ clay) & 166 & 4.9 & 6.8 & 71 & 0.1 & 0.62 \\
\hline $14-3(80-90)$ & 125 & Lower Eocene & Brown-radiolarian ooze & 164 & 4.9 & 6.8 & 62 & 0.1 & 0.38 \\
\hline $15-5(-)$ & 136 & Lower Eocene & Brown-radiolarian ooze & 166 & - & - & - & - & - \\
\hline $16-3(31-42)$ & 142 & Lower Eocene & Brown-radiolarian ooze & 170 & 4.7 & 6.8 & 69 & 0.1 & 0.44 \\
\hline \multicolumn{10}{|c|}{ Hole $42\left(13^{\circ} 50.56^{\prime} \mathrm{N}, 140^{\circ} 11.31^{\prime} \mathrm{W}\right.$, water depth $4848 \mathrm{~m} ., 500$ miles $\mathrm{S}$. of Hole 40$)$} \\
\hline $1-3(110-120)$ & 4 & Upper Oligocene & $\begin{array}{l}\text { Orange to yellow-brown radiolarian- } \\
\text { nannofossil ooze (firm) }\end{array}$ & 185 & 5.8 & 6.9 & 88 & 0.1 & - \\
\hline $4-3(110-120)$ & 31 & Lower Oligocene & Radiolarian-nannofossil ooze & 166 & 5.6 & 7.1 & 71 & 0.1 & 0.24 \\
\hline $6-4(15-25)$ & 51 & Upper Eocene & $\begin{array}{l}\text { Yellow-medium brown radiolarian- } \\
\text { nannofossil ooze }\end{array}$ & 162 & 5.4 & 6.8 & 75 & 0.1 & 0.61 \\
\hline $8-5(90-102)$ & 70 & Middle Eocene & $\begin{array}{l}\text { Radiolarian-nannofossil ooze, } \\
\text { pumice fragment }\end{array}$ & 156 & 5.2 & 7.1 & 72 & 0.1 & 0.32 \\
\hline $10-2(-)$ & 84 & Middle Eocene & Firm radiolarian-nannofossil ooze & 146 & - & - & - & - & 0.18 \\
\hline $10-3(79-89)$ & 86 & Middle Eocene & $\begin{array}{l}\text { Firm radiolarian-nannofossil ooze, } \\
\text { pumice fragment }\end{array}$ & 172 & 5.2 & 7.1 & 66 & 0.1 & 0.18 \\
\hline
\end{tabular}

${ }^{\mathrm{a}}$ Core-Section (interval). 
TABLE 4

Trace Constituents of Interstitial Water, Leg 5

From Large Volume $(\sim 100 \mathrm{ml})$ Squeezing

\begin{tabular}{lcccccccc}
\hline $\begin{array}{c}\text { Sample } \\
\text { Designation }\end{array}$ & $\begin{array}{c}\text { Depth Below } \\
\text { Sea Bed } \\
(\mathrm{m})\end{array}$ & $\begin{array}{c}\mathrm{Fe} \\
(\mu \mathrm{g} / \mathrm{kg})\end{array}$ & $\begin{array}{c}\mathrm{Co} \\
(\mu \mathrm{g} / \mathrm{kg})\end{array}$ & $\begin{array}{c}\mathrm{Ni} \\
(\mu \mathrm{g} / \mathrm{kg})\end{array}$ & $\begin{array}{c}\mathrm{Cu} \\
(\mu \mathrm{g} / \mathrm{kg})\end{array}$ & $\begin{array}{c}\mathrm{Mn} \\
(\mu \mathrm{g} / \mathrm{kg})\end{array}$ & $\begin{array}{c}\mathrm{Zn} \\
(\mu \mathrm{g} / \mathrm{kg})\end{array}$ & $\begin{array}{c}\mathrm{Si}^{\mathrm{a}} \\
(\mathrm{mg} / \mathrm{kg})\end{array}$ \\
\hline $34-4-4$ & 110 & 14 & 1 & 32 & 15 & - & 190 & 27 \\
$36-11-0$ & 92 & 15 & 1 & 10 & 15 & 2440 & 210 & 8 \\
$40-15-5$ & 136 & 45 & 1 & 11 & 6 & 140 & 180 & 3 \\
$42-10-2$ & 84 & 9 & 1 & 6 & 4 & 90 & 180 & 30 \\
\hline
\end{tabular}

${ }^{\mathrm{a}}$ Separate split of water $(\sim 10 \mathrm{ml})$ was kept frozen from time of collection until time of analysis.

nodules are reportedly present in the sediment and could have undergone oxidation when exposed to the atmosphere, possibly lowering the $p \mathrm{H}$. However, as can be seen, several samples gave a $p \mathrm{H}$ reading of 7.1, which is significantly lower than the 7.5 to 7.8 values the authors have found to be typical for pore water.

The E $h$ values are all highly positive; some seem to be unreasonably so, especially those for Hole 35 , and possibly, Hole 34 , where active sulfate reduction has occurred. It is not possible to assess their significance at this time.

A gas chromatographic determination of total dissolved carbon dioxide was carried out on board ship using only 0.2 milliliter of water. Because of the small sample size, measurement errors are probably present. The general trends, however, agree with those of the total alkalinity measurements made by Manheim et al. Of particular interest, is the notable decrease in total dissolved carbonate with depth in some cores. In some cases, for example, Holes 33,35 and 36 , the concentration apparently drops to below that in surface sea water, suggesting that dissolved bicarbonate is entering the diagenetic cycle.

Manheim et al. (this volume) have commented on trends in the concentration of the major and minor constituents of the interstitial water from Leg 5; and, little can be added to their discussion, especially since they analyzed considerably more samples from more holes than were made available to UCLA. As they report here, and as the authors have pointed out previously (Leg 1 and especially Leg 4), rather drastic changes in the concentration of magnesium, potassium and calcium are common in JOIDES interstitial water. In the cores analyzed at UCLA, the trend with depth has always been one of increasing calcium and decreasing magnesium and potassium. This trend is exhibited by cores from Hole 34 but not by those from Hole 36 ,
40 and 42 (Table 2). In fact, the interstitial water chemistry is almost constant with depth in these three holes.

The relative constancy of the interstitial water chemistry in Holes 36, 40 and 42 seemed at first to indicate contamination of the interstitial water of these rather permeable biogenic oozes with drilling fluid. However, the evidence that some cores could have suffered little or no contamination (for example, no sulfate was found in some Leg 4 waters) makes extensive contamination unlikely. Evidence for diagenetic change in the interstitial water chemistry must depend on a combination of factors, including: sedimentation rate, time of burial, mineralogy of the sediment and, possibly, temperature.

The tendency for lithium to increase in concentration with depth in "diagenetically active" locations was very pronounced in Leg 4 samples, and shows up here in Hole 34 (Table 2). The data of Manheim et al. show an even more drastic increase in lithium concentration in this hole. It is not clear why the two sets of lithium concentration data agree in the range of near sea water values, but disagree when high values are concerned. The authors have checked their technique by spiking sea water with lithium, and can find no errors in their method.

Manheim et al. (this volume) have compared the data obtained by their group with the UCLA data for those samples analyzed by both groups; and, as they point out, the agreement for most elements is generally good. The authors have commented on the small chloride discrepancy, and the sulfate and lithium differences above. In addition, they agree that the bromide values show more scatter than is reasonable (and more than they have obtained on samples from other legs), and would suggest accepting the Woods Hole data as more correct. 
It is thought worthwhile to point out some significant instances of agreement, which indicate that sharp changes in the analytical data are not due to random error. For example, the chloride in the six samples from Hole 36 show an identical pattern of decreasing then increasing then decreasing concentration with depth, with the UCLA value-in every case-exactly 0.3 per mil higher than the Woods Hole one (this bias has been discussed above). Another interesting example is the sample from 67 meters depth in Hole 36. Both groups show it to be about $100 \mathrm{ppm}$ higher in potassium concentration than the sample on either side of it, and to be significantly lower in magnesium, suggesting that the sample may have warmed up before it was squeezed. The carbon dioxide data provide similar examples. Note that both groups show the bottom sample in Hole 33 to be significantly depleted relative to the other samples in the hole.

\section{SUMMARY}

The data presented in this report are of a descriptive nature only, to give added information of the cores and environment of deposition and accumulation. Although only very small volumes of water were available for an extensive analytical program, the data obtained by the UCLA group shows reasonably good agreement with those obtained by Manheim et al. at Woods Hole. Some exceptions to this are discussed in the report, and improved techniques for studies of subsequent water may help eliminate these differences. The shipboard data, especially $p \mathrm{H}$ and $\mathrm{E} h$, could be in error for several reasons, and may not be entirely reliable.

Maximum changes are seen to occur in magnesium, calcium, potassium, sulfate and dissolved carbonate. The total salinity shows little variation over its concentration in sea water. There is no obvious membrane filtration effect with depth. Lithium appears to be highly enriched at depth, but only in some cores, mainly those containing terrigenous sediments. Manganese is enriched in many samples, but its distribution appears to be random.

\section{REFERENCES}

Baltre, P., 1963. Colorimetric determination of small quantities of bromide in the presence of a large excess of chloride. J. Pharm. Chim. Ser. 2, 24, 409.

Brooks, R. R., Presley, B. J. and Kaplan, I. R., 1967. APDC-MIBK extraction system for the determination of trace metals in saline waters by atomicabsorption spectrophotometry. Talanta.. 14, 809.

1968. Trace elements in the interstitial waters of marine sediments. Geochim. Cosmochim. Acta. 32, 397.

Culkin, F., 1965. The major constituents of sea water. In Chemical Oceanography. J. P. Riley and G. Skirrow (Eds.). (Academic Press) 1, 121.

Hays, M. R. and Metcalfe, J., 1962. The boron-curcumin complex in the determination of trace amounts of boron. Analyst. 87, 956.

McCrea, J. M., 1950. On the isotopic chemistry of carbonates and a paleotemperature scale. J. Chem, Phys. 118, 849 .

Presley, B. J., Brooks, R. R. and Kaplan, I. R., 1967. Manganese and related elements in the interstitial water of marine sediments. Science. 158, 906.

Presley, B. J., and Kaplan, I. R., 1968. Changes in dissolved sulfate, calcium and carbonate from interstitial water of near shore sediments. Geochim. Cosmochim. Acta. 32, 1037.

Presley, B. J., 1.969. Chemistry of interstitial water from marine sediments. (Ph.D. thesis, UCLA).

Strickland, J. D. H. and Parsons, T. R., 1968. A practical handbook of seawater analysis. Bull. Fisheries Res. Board of Canada. 167. 